\title{
FIRST REPORT OF LASIODIPLODIA THEOBROMAE CAUSING NEEDLE BLIGHT AND STEM CANKER DISEASES ON ARAUCARIA HETEROPHYLLA IN ETHIOPIA
}

\author{
Short communication \\ Wendu Admasu DARGE* \\ Central Ethiopia Environment and Forest Research Center, Forest protection Process \\ Addis Ababa, P.o. Box-30708, Ethiopia \\ Received: April 2017; Accepted: October 2017
}

\begin{abstract}
Canker and needle blight of Araucaria heterophylla (Norfolk Island pine) trees were observed during the surveys conducted in Addis Ababa and Adama cities (Ethiopia) from November to December 2016. The main objective of this study was to investigate fungal pathogens that cause diseases on Araucaria heterophylla trees. Six localities with Araucaria heterophylla plantings were purposively surveyed for disease symptoms. Samples from symptomatic parts of trees were collected, surface sterilized, cultured on PDA and morphologically identified for genus and species. A total of 36 isolates of fungi were identified. Based on macro- and microscopic morphological features of the colonies, the fungal isolates were found to be the genus Diplodia and species Lasiodiplodia theobromae (Pat.) Griffon \& Maubl (syn. Botryodiplodia theobromae), the anamorph of Botryosphaeria rhodina (Berk. \& M.A. Curtis) Arx. The pathogenicity test showed that the isolates of Lasiodiplodia theobromae, caused stem canker and needle blight on Araucaria heterophylla. This finding is important in the study of management options for future prevention and control of diseases in the country.
\end{abstract}

Key words: Araucaria heterophylla, Lasiodiplodia theobromae, needle blight, stem canker

\section{INTRODUCTION}

Araucaria heterophylla is a distinctive conifer, a member of the family Araucariaceae. Currently, it grows extensively all over the world in different climate regions due to its pleasing appearance, fairly broad climatic adaptability as well as their ornamental nature. The trees are planted either as single individuals or in avenues of urban streets, and as indoor plants (Patil et al. 2014). The growth of this tree is currently affected by infections caused by Phytophthora spp. manifesting with the wilt of plants and yellow discoloration of needles. Dying of branches, red band needle blight and canker are also the symptoms of other diseases caused by the fungi Dothistroma septosporum, Colletotrichum derridis and Lasiodiplodia theobromae, resulting in heavy defoliation of needles of trees of all ages (Ridley \&
Dick 2001). Lasiodiplodia theobromae is a common endophyte and an opportunistic pathogen of more than 500 tree species in the tropics and subtropics, also causing cankers and dieback of ornamental plants, vegetable crops, perennial fruit and nut trees (Sulaiman et al. 2012; Úrbez-Torres et al. 2008; Hseu et al. 2008; French 2006; Khanzada et al. 2004). Golzar \& Burgess (2011) also reported that Diplodia species can cause canker and decline diseases of the Norfolk Island pine in New Zealand and Australia. Araucaria heterophylla is currently among the exotic trees rapidly expanding in the recent years in Ethiopian cities like Addis Ababa and Adama at interior locations such as homes, apartments, offices, public buildings, shopping malls and urban streets, home gardens and parks; this makes them vulnerable to various stresses and susceptible to various infections (Ma et al. 2001; Slippers et al. 
2005; Dakin et al. 2010). The objective of this study was to identify fungal pathogen associated with $\mathrm{Ar}$ aucaria heterophylla disease observed on plantings in Addis Ababa $\left(8^{\circ} 50^{\prime}-9^{\circ} 05^{\prime} \mathrm{N}\right.$ and $38^{\circ} 39^{\prime}-38^{\circ} 55^{\prime}$ $\mathrm{E}$, in the altitude ranging from 2350 to $3300 \mathrm{~m}$ above sea level), and Adama (about $100 \mathrm{~km}$ South East of Addis Ababa with an average altitude of $1620 \mathrm{~m}$ above sea level).

\section{MATERIAL AND METHODS}

Araucaria heterophylla trees in streets, parks, nurseries and interior locations (homes, apartments, offices and public buildings) were surveyed from November to December 2016 for disease symptoms. Diseased samples of needles and segments of stems with symptoms of blight and canker were collected from six localities. They were washed thoroughly with tap water, cut into $1 \mathrm{~cm}$ long pieces, and surface sterilized with dipping in $90 \%$ ethanol solution. Then they were washed thoroughly with sterile distilled water several times. Next, the pieces were transferred individually on potato dextrose agar (PDA) in Petri dishes, and incubated at $25-30{ }^{\circ} \mathrm{C}$ for $7-8$ days. The developed fungal colonies were purified using hyphals or single spores. Micromorphological descriptions of mature conidiomata and conidia for 36 fungal cultures were carried out after 4 weeks of incubation using slides mounted in water following the methods described by Adeniyi et al. (2016). Colony colors on the surface and reverse were assessed according to the color charts (Rayner 1970). Fungal cultures were identified at genus and species level based on macroscopical (color, texture, shape and appearance) and microscopical traits (conidia shape, hyphae color, septation, concentric zone, pigmentation, fruiting bodies) using identification keys of Agrios (2002), Gezahgne et al. (2014), Sulaiman et al. (2012).

Pathogenicity of fungal isolates was tested using detached leaf techniques of respective host

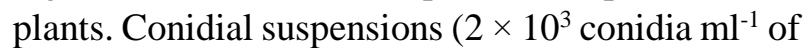

sterile water) of the isolates were used for the test procedure. Needles were superficially disinfected with $70 \%$ ethanol and rinsed with sterile distilled water, then sprayed with spore solution and kept in humid plastic bags at room temperature. Sterile water free of fungal spores was used to spray the control. Disease symptoms developed on the needles were recorded and fungus was re-isolated from the diseased host tissues to confirm identity with the inoculated fungal isolates according to the procedures of Xue et al. (2004).

\section{RESULTS}

The survey of Araucaria heterophylla plants grown in Addis Ababa and Adama cities showed severe needle blight and stem canker with brown coloration as the most common disease symptoms (Fig. 1).

A total of 36 pure cultures of fungi colonies assumed to be associated with stem canker and needle blight of Araucaria heterophylla isolated from six localities (six pure cultures from each) were characterized and identified.

The mycelium of the isolated fungus grew vigorously on the PDA. The dense aerial parts of mycelia grew uniformly in all directions and fully covered the surface of the media within 3 to 4 days. The color of the colony changed gradually from light grey after four to seven days of incubation (Fig. 2 A) to black after 2 weeks of incubation. The bottom part of the fungus became darker only after 3 weeks of incubation. Subsequently, the fungus produced stromata and pycnidia. The pycnidia were initially soft but hardened with the culture maturing at 4 weeks. The culture sporulated after 4 weeks of incubation. Light microscope observations showed that the fungus produced immature conidia with some distinct features. They were non-septated, thick cell-walled, oval in shape and hyaline. However, the mature conidia were septate, oval-shaped and brown in color with the presence of irregular longitudinal striations (Fig. 2 B). 

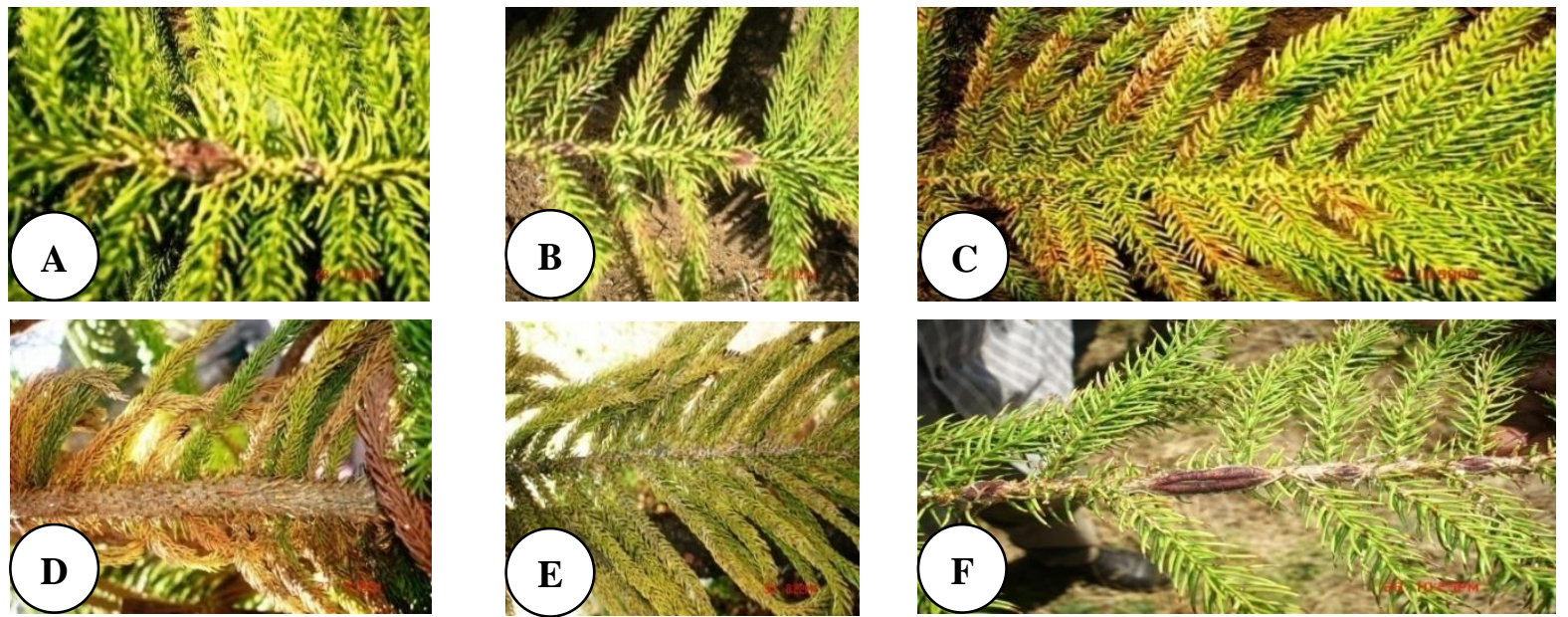

Fig. 1. Stem canker and needle blight due to pathogenic fungi on Araucaria heterophylla (A, B, C, D, E, F), Adama and Addis Ababa cities
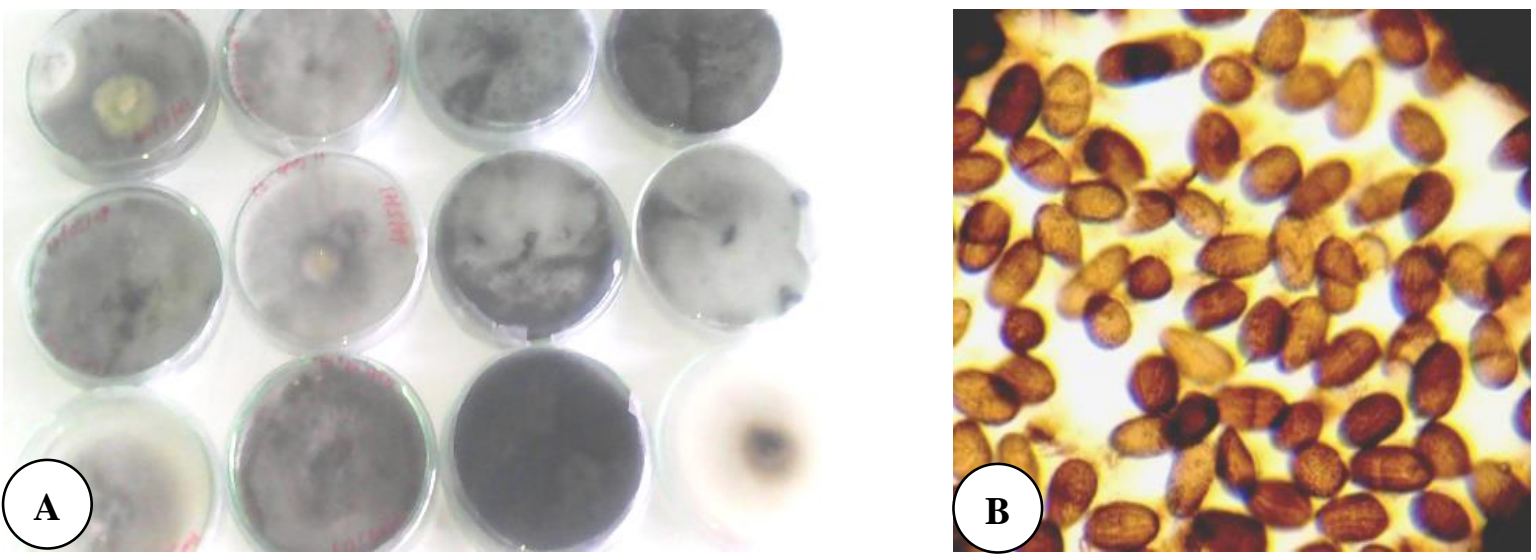

Fig. 2. Fungal cultures from Araucaria heterophylla on PDA (A) and conidia (B) after 7 days showing Lasiodiplodia theobromae

The morphological features of all fungal isolates were typical to the genera belonging to Diplodia. Based on microscopic morphological features of the fungal conidia, all the isolates were further identified to species level as Lasiodiplodia theobromae. There were no significant differences in morphology and in the rate of mycelia growth among the isolates, regardless of place of origin.

These morphological characteristics were identical with the description of Lasiodiplodia theobromae (Pat.) Griffon \& Maubl (syn. Botryodiplodia theobromae), the anamorph of Botryosphaeria rhodina (Berk \& Curtis Arx described by Gezahgne et al. in 2014). Another important morphological characteristic for the identification of $L$. theobromae is the presence of aseptate paraphyses observed in immature pycnidia. This feature was reported in a recent study, in which aseptate paraphyses along with conidial size were the primary morphological characteristics to separate $L$. theobromae from other
Lasiodiplodia found in the tropics with conidia, similar to those described for L. theobromae in shape, color and striation, as reported by Adeniyi et al. (2016). Pathogenicity test using spore suspension of L. theobromae isolates on the A. heterophylla needles revealed their pathogenicity, showing typical symptoms of the disease after 10 days of inoculation. The re-isolation of the pathogen using standard procedure confirmed their affiliation to the $L$. theobromae.

According to the studies by Dakin et al. (2010) and others, trees which are under environmental stress or with mechanical injuries can be vulnerable to attack by opportunistic fungal pathogens such as Diplodia resulting in stem canker, needle and shoot blight. Slippers et al. (2005) also showed that members of the Botryosphaeriaceae have been reported causing aggressive diseases on Araucaria cunninghamii and other conifer tree species. Bihon et al. (2011) stated that Diplodia species are widely distributed opportunistic pathogens of conifers like Pinus spp. worldwide. 


\section{CONCLUSION}

This study helped to figure out the incidence and severity level of needle blight and stem cancer diseases of A. heterophylla in Addis Ababa and Adama cities of Ethiopia. The causal fungal pathogen was identified as Lasiodiplodia theobromae (Pat.) Griffon \& Maubl (syn. Botryodiplodia theobromae), the anamorph of Botryosphaeria rhodina (Berk \& Curtis) Arx. The findings of this research are important in the study of management options for prevention and control of the diseases in the country.

\section{Acknowledgement}

This study was funded by Central Ethiopia Environment and Forest Research (CEE-FRC). The authors thank Ato Abraham Yirgu, Forest Protection Process researcher, for his kind words, strengths and comments during the field and laboratory works. Finally, the author is extremely grateful to the laboratory assistants of Forest Protection Process for their valuable assistance during the laboratory phase of the research.

\section{REFERENCES}

Adeniyi D.O., Olufolaji D.B., Joseph A. 2016. Characteristic variations in Lasiodiplodia theobromae; pathogen of inflorescence dieback of cashew in growing ecologies of Nigeria. Annual Research \& Review in Biology 10(2): 1-6. DOI: 10.9734/2016/ARRB/18047.

Agrios G.N. 2002. Plant pathology. $5^{\text {th }}$ edition, Academic Press, USA, 952 p.

Bihon W., Burgess T., Slippers B., Wingfield M.J., Wingfield B.D. 2011. Distribution of Diplodia pinea and its genotypic diversity within asymptomatic Pinus patula trees. Australasian Plant Pathology 40(5): 540-548. DOI: 10.1007/s13313-011-0060-z.

Dakin N., White D., Hardy G.E.S.J., Burgess T.I. 2010. The opportunistic pathogen, Neofusicoccum australe, is responsible for crown dieback of peppermint (Agonis flexuosa) in Western Australia. Australasian Plant Pathology 39: 202-206. DOI: 10.1071/ap09085.

French B.R. 2006. Diseases of food plants in Papua New Guinea - a compendium. Australia, 302 p.

Gezahgne A., Yirgu A., Kassa H. 2014. First report of Lasiodiplodia theobromae causing canker on tapped Boswellia papyrifera trees in Ethiopia. New
Disease Reports 29: 11. DOI: 10.5197/j.20440588.2014.029.011.

Golzar H., Burgess T.I. 2011. Neofusicoccum parvum, a causal agent associated with cankers and decline of Norfolk Island pine in Australia. Australasian Plant Pathology 40: 484-489. DOI: 10.1007/s13313-011-0068-4.

Hseu S.H., Zeng W.F., Lai W.C., Pan Y.P., Lin C.Y. 2008. Fruit rot disease of pineapple caused by Burkholderia gladioli. Plant Pathology Bulletin 17: 157-167.

Khanzada M.A., Lodhi A.M., Shahzad S. 2004. Mango dieback and gummosis in Sindh, Pakistan caused by Lasiodiplodia theobromae. Plant Health Progress. Online. DOI: 10.1094/PHP-2004-0302-01-DG.

Ma Z., Morgan D.P., Michailides T.J. 2001. Effects of water stress on Botryosphaeria blight of pistachio caused by Botryosphaeria dothidea. Plant Disease 85: 745-749. DOI: 10.1094/pdis.2001.85.7.745.

Patil A.R., Darekar A.B., Saudagar R.B. 2014. Araucaria heterophylla: the review. World Journal of Pharmacy and Pharmaceutical Sciences 3(1): 221-232.

Ridley G.S., Dick M.A. 2001. An introduction to the diseases of forest and amenity trees in New Zealand. Forest Research Bulletin 220, 110 p.

Rayner R.W. 1970. A mycological colour chart. CMI and British Mycological Society, Kew, Surry, 34 p.

Sulaiman R., Thanarajoo S.S., Kadir J., Vadamalai G. 2012. First report of Lasiodiplodia theobromae causing stem canker of Jatropha curcas in Malaysia. Plant Disease 96(5): 767. DOI: 10.1094/pdis06-11-0482-pdn.

Slippers B., Summerell B.A., Crous P.W., Coutinho T.A., Wingfield B.D., Wingfield M.J. 2005. Preliminary studies on Botryosphaeria species from Southern Hemisphere conifers in Australasia and South Africa. Australasian Plant Pathology 34: 213-220. DOI: 10.1071/ap05020.

Úrbez-Torres J.R., Leavitt G.M., Guerrero J.C., Guevara J., Gubler W.D. 2008. Identification and pathogenicity of Lasiodiplodia theobromae and Diplodia seriata, the causal agents of bot canker disease of grapevines in Mexico. Plant Disease 92(4): 519529. DOI: 10.1094/pdis-92-4-0519.

Xue A.G., Armstrong K.C., Voldeng H.D., Fedak G., Babcock C. 2004. Comparative aggressiveness of isolates of Fusarium spp. causing head blight on wheat in Canada. Canadian Journal Plant Pathology 26(1): 81-88. DOI: 10.1080/07060660409507117. 